Arslan H., Topal A. \& Dönük G. D. (2020). Türkiye'de Geleneksel Medya ve Yeni Medyada Kadın Kimliği Üzerinden Üretilen Haberlere Eleştirel Bakış. Dördüncü Kuvvet. 3 (1). 21-38

\title{
TÜRKIYE'DE GELENEKSEL MEDYA VE YENI MEDYADA KADIN KIMLIĞĞ ÜZERINDEN ÜRETILEN HABERLERE ELEŞTIREL BAKIŞ
}

\author{
Hicabi Arslan ${ }^{1}$ \\ Aslıhan Topal ${ }^{2}$ \\ Gizem Gürel Dönük ${ }^{3}$
}

\section{Özet}

Günümüzde, iletişim teknolojilerinde yaşanan gelişmeler sayesinde etrafımızda olan biten her şeyi en ince detayları ile hızlı bir şekilde öğreniyoruz. Bu anlık iletiler, insanların ruhunda var olan, etrafında olup biteni öğrenme merakını fazlasıyla gidermektedir. Ancak yeni iletişim teknolojilerinin sunduğu enformasyona ulaşım hızı, içerisinde birtakım farklı unsurları da barındırmaktadır. Bireylerin bu kadar kolay ulaştığı her enformasyon içeriği doğru mu, verilen görseller gerçeği ne kadar yansıtıyor, aktarılanların sunumunda etik kurallara ne kadar uyuluyor, mahremiyet ya da gizlilik kavramlarının bu gelişim, değişim içerisinde uğradığ 1 dönüşüm etik anlamda nasıl değerlendirilmelidir? $\mathrm{Bu}$ ve benzeri sorular yaşanılan dönüşümde titizlikle çalışılmayı gerektiren konulardan yalnızca birkaçı olarak karşımızda durmaktadır. Bu çalışmada özellikle kadın kimliğinin, değişen ve gelişen iletişim teknolojileri içerisinde anlık iletilerin, enformasyon yığını içerisinde aktarılanların sunumunun geleneksel medya ve yeni medyada üretilen haberler üzerinden etik anlamda değerlendirmesi gerçekleştirilecektir. Bu kapsamda çalışma Emine Bulut, Şule Çet, Ceren Özdemir, Ayşe Tuba Arslan, Fatma Nur Çelik, Şefika Etik, Münevver Karabulut, Özgecan Aslan cinayetlerinin geleneksel ve yeni medyada sunumu üzerinden yürütülecektir.

Anahtar Kelimeler: Yeni Medya, Geleneksel Medya, Etik, Kadın Kimliği

\footnotetext{
${ }^{1}$ Doktor Öğretim Üyesi. Aydın Adnan Menderes Üniversitesi. harslan@adu.edu.tr. ORCID: 0000-0001-9424-7722

${ }^{2}$ Öğretim Görevlisi. Aydın Adnan Menderes Üniversitesi. topal.aslihan@adu.edu.tr. ORCID:0000-0003-3111$\underline{824 \mathrm{X}}$

${ }^{3}$ Öğretim Görevlisi. Aydın Adnan Menderes Üniversitesi. gizem.gurel.donuk@adu.edu.tr. ORCID: 0000-00024171-999X
} 
Arslan H., Topal A. \& Dönük G. D. (2020). Türkiye'de Geleneksel Medya ve Yeni Medyada Kadın Kimliği Üzerinden Üretilen Haberlere Eleştirel Bakış. Dördüncü Kuvvet. 3 (1). 21-38

\title{
A CRITICAL VIEW OF THE NEWS PRODUCED IN THE TRADITIONAL MEDIA AND NEW MEDIA THROUGH FEMALE IDENTITY IN TURKEY
}

\begin{abstract}
Today, thanks to the developments in communication technologies, we learn everything that happens around us incredibly quickly. These instant messages overcome the curiosity of learning what's going on around the people's soul. However, this situation contains a number of different elements with the speed of access to the information provided by new communication technologies. Is every information content that individuals reach so easily correct? or how much do the visuals reflect the truth? how should this transformation of privacy concepts undergo change in an ethical sense? questions such as these are just a few of the issues that require meticulous work in the transformation. In this study, ethical evaluation of women's identity, presentation of instant messages within the changing and developing communication technologies, and those conveyed in the information stack will be carried out ethically on traditional media and news produced in the new media. In this context, the work will be carried out through the presentation of the murders of Emine Bulut, Şule Çet, Ceren Özdemir, Ayşe Tuba Arslan, Fatma Nur Çelik, Şefika Etik, Münevver Karabulut, Özgecan Aslan in traditional and new media.
\end{abstract}

Keywords: New Media, Traditional Media, Ethics, Women Identity 
Arslan H., Topal A. \& Dönük G. D. (2020). Türkiye'de Geleneksel Medya ve Yeni Medyada Kadın Kimliği Üzerinden Üretilen Haberlere Eleştirel Bakış. Dördüncü Kuvvet. 3 (1). 21-38

\section{Giriş}

Medya kavramı; gazete, dergi, radyo, televizyon, internet gibi kitle iletişim araçları olarak tanımlanmaktadır (Aydeniz, 2012:16). En genel ifadeyle kitlesel düzeyde iletişimi gerçekleştiren araçlar olarak ifade edilebilir. Bu araçlarla ilgili ortaya çıkışından günümüze kadar pek çok gelişme ve değişim yaşanmıştır. Günümüzde medya endüstrisine genel olarak bakıldığında yaşanan değişim daha net olarak anlaşılabilecektir. Artık hayatımızın her anında bizimle yer alan yeni iletişim teknolojilerinin varlığı yadsınamaz derecede insan hayatında etkili olmaktadır. Bu etki sadece pozitif anlamda değil negatif boyutuyla da değerlendirilmesi gereken bir noktadadır.

Medyanın insanları etkilediği ortadadır. Ancak unutulmaması gereken bir nokta; günümüz koşulları içerisinde insanların kendi tercihleri doğrultusunda istedikleri kitle iletişim aracını, istedikleri oranda takip ettikleri gerçeğidir. Bireylerin medyayı hangi amaçla ne için ne kadar süreyle, nerede kullandıkları ve özellikle son dönemde yeni medya ile eskiye göre içerik üretimi yönünden etkin konumda bulunmaları, bu etkilenme düzeyinde tamamen pasif konumda olmadıklarını, aktif bir rol oynadıklarını ortaya koymaktadır. Yeni medya kavramı ile birlikte birey, geleneksel medya içerisinde içerikleri tüketen konumunda bulunan, sunulanlar arasından tercihini yaparak aktarılanı almakta ya da hiç almamakta iken şimdi sunulanlar üzerinde direkt olarak etkide bulunabilmektedir. Bunlara Whatsapp ihbar hattı, Bip uygulaması ile sosyal medya üzerinden bir haberci gibi çektiği fotoğrafı ya da videoyu paylaşan bireyler örnek gösterilebilmekte ve bu bireylerin medyada sunulan içeriklerle arasındaki etkileşimin farklılaştığı gerçeğini ortaya koymaktadır. Sadece bu uygulamalar değil, sosyal medyanın kullanıcı odaklı, kullanıcıların özgürlüklerini doyasıya yaşadıkları bir mecra olarak, aslında genel gidişat açısından gayet tehlikeli bir mecra olarak karşımızda durmakta olduğunu göstermektedir. İçerik kontrolü sağlanamayan, her isteyenin her istediğini, istediği şekilde paylaştığı bu mecra zaman, mekân, gizlilik, mahremiyet kavramlarının perdelerini açarak sınırları ihlal etmektedir. Bunun pek çok örneği sürekli, neredeyse anlık olarak yaşanmaktadır. Yapılan paylaşımlarda bireylerin birbirlerine yaptıkları hakaretler, özel yaşamın ifşa edilmesi, hayatların neredeyse kurgulanarak bu mecralar üzerinden yaşandığı gözlenmektedir.

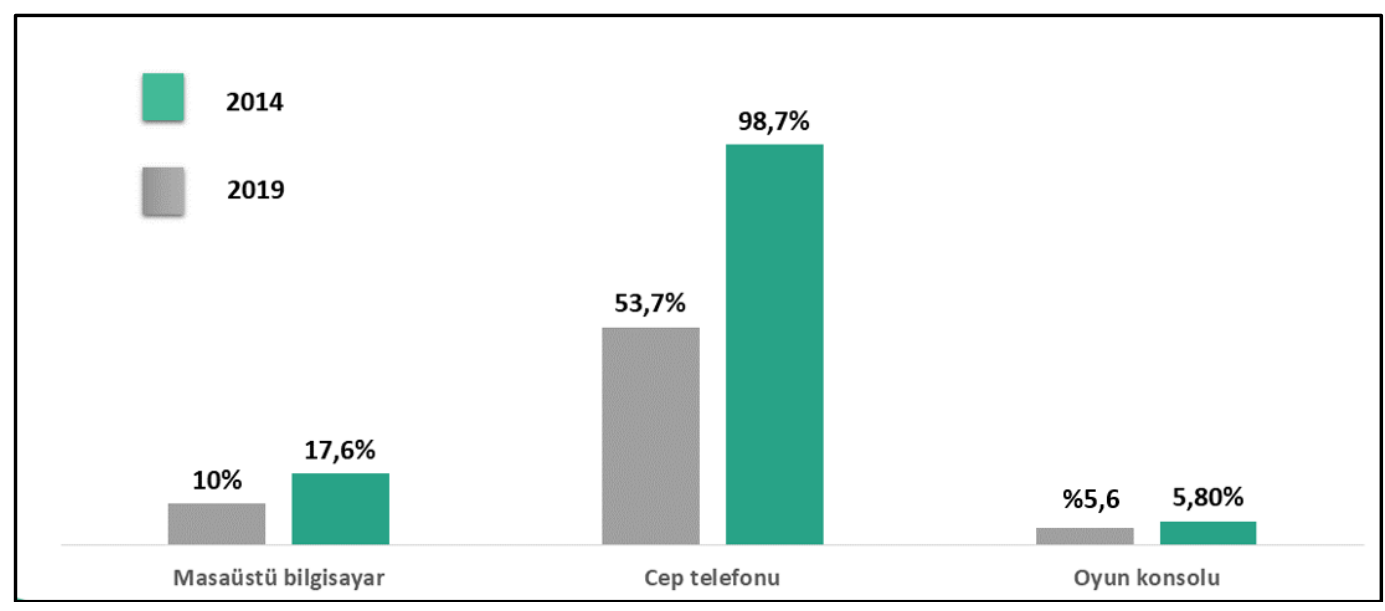

Şekil 1. Bilişim Teknolojileri Kullanım Oranları

Kaynak: https://dijilopedi.com/2019-tuik-hanehalki-bilisim-teknolojileri-kullanim-arastirmasi/ Erişim Tarihi:07.02.2020

İletişim alanında yaşanan gelişmeler, deyim yerindeyse ülkeler arasındaki mesafeyi kısaltırken, toplumların birbirine yaklaşmalarını, insanların daha fazla kaynaşmalarını sağlamıştır. Bilgi toplumu açısından konu değerlendirildiğinde artık bir tık uzağımızdaki internet ortamında tüm bilgiler 
Arslan H., Topal A. \& Dönük G. D. (2020). Türkiye'de Geleneksel Medya ve Yeni Medyada Kadın Kimliği Üzerinden Üretilen Haberlere Eleştirel Bakış. Dördüncü Kuvvet. 3 (1). 21-38

avucumuzun içerisinde yer almaktadır. TÜIK' in internet ve sosyal medya kullanımına yönelik verileri incelendiğinde artık internetin girmediği ev, internetle tanışmayan birey ki buna en küçük yaş grubu bireyler de dâhil neredeyse kalmamıştır. Bu kadar hızlı yaşanan gelişmelerin ışığında, bilgi toplumu dijital toplum formuna fazlasıyla alışmış görünmektedir. Artık neredeyse bir organı haline gelmiş, ellerinden akı1lı telefonları hiç düşmeyen, ne olursa tüketen bireyden haberci üreten bireye dönüşen toplumsal yapı içerisinde kadın kimliğinin medyada sunumu da farklılıklar göstermektedir.

\begin{tabular}{|lccc|}
\hline Amaçlar & Toplam & Erkek & Kadın \\
E-Posta gönderme / alma & $\mathbf{4 6 , 2}$ & 52,5 & 38,8 \\
İnternet üzerinden telefonla görüşme/ video görüşmesi & $\mathbf{8 2 , 7}$ & $\mathbf{8 0 , 7}$ & $\mathbf{8 5 , 0}$ \\
Sosyal medya üzerinde profil oluşturma, mesaj gönderme veya fotoğraf & $\mathbf{8 1 , 4}$ & $\mathbf{8 4 , 5}$ & $\mathbf{7 7 , 7}$ \\
vb. içerik paylaşma & $\mathbf{9 3 , 9}$ & 93,3 & 94,6 \\
Mesajlaşma & $\mathbf{6 9 , 8}$ & $\mathbf{7 4 , 5}$ & 64,3 \\
Çevrimiçi haber okuma & $\mathbf{6 9 , 3}$ & 65,9 & $\mathbf{7 3 , 2}$ \\
Sağlıkla ilgili bilgi arama (yaralanma, hastalık, beslenme, vb.) & $\mathbf{6 5 , 0}$ & 68,5 & 60,9 \\
Mal ve hizmetler hakkında bilgi arama & $\mathbf{2 3 , 6}$ & 25,8 & 20,9 \\
Web siteleri aracılığıyla görüş paylaşma & $\mathbf{9 , 1}$ & 11,0 & 6,8 \\
Toplumsal veya siyasal bir konuda online bir oylamaya katılma & $\mathbf{1 0 , 6}$ & 11,2 & 9,9 \\
İş arama ya da iş başvurusu yapma & $\mathbf{4 2 , 5}$ & 44,5 & 40,2 \\
Kendi oluşturduğunuz metin, fotoğraf, müzik, video, yazılım vb. içerikleri & $\mathbf{7 1 , 5}$ & 72,6 & 70,2 \\
herhangi bir web sitesine paylaşmak üzere yükleme & $\mathbf{4 7 , 1}$ & 59,0 & 33,0 \\
Müzik dinlemek (Web radyosu dahil) & & & \\
İnternet bankacılığı & & & \\
\hline
\end{tabular}

Şekil 2. Internet Kullanan Bireylerin Interneti Kişisel Kullanma Amaçları

Kaynak: https://dijilopedi.com/2019-tuik-hanehalki-bilisim-teknolojileri-kullanim-arastirmasi Erişim Tarihi: 07.02.2020

Günümüzde, iletişim teknolojilerinde yaşanan gelişmeler sayesinde etrafımızda olan biten her şeyi çok hızlı bir şekilde öğreniyoruz. Bu anlık iletiler, insanların ruhunda var olan, etrafında olup biteni öğrenme merakını fazlasıyla gidermektedir. Hayatımızın içerisinde bu kadar etkili olan yeni medya kavramını tanımlamadan önce geleneksel medya kavramının tanımını yapmak ve her iki kavram arasındaki farklara değinmek gerekmektedir.

Geleneksel medya ve yeni medyanın etkileri üzerine günümüzde sıklıkla değerlendirmeler, incelemeler yapılmaktadır. Bireyler hayatlarında olup bitenleri aktarmak, yakın çevrelerinde olan bitenleri öğrenmek, meraklarını gidermek adına, eğlenmek, öğrenmek, paylaşmak adına pek çok nedenle iletişim halindedir. İletişim varlığımızla birlikte var olan bir kavram olarak olmazsa olmazdır. İletişim halimiz yeni teknolojik gelişmelerle etik bağlamda değişikliğe uğrar görünmektedir.

Bireylerin sosyal yaşamları bile yeni medyanın etkileri ile şekillenmektedir. Yemek siparişi vermeden, çiçek siparişine, her türlü alışverişten, kitap okumaya çok farklı etkinliklerde bulunulabilmektedir. Sadece bunlarla kalmayıp sosyal medya üzerinden tanışıp evlenenler, dolandırıcılık eylemleri, tehditler, hayatları alt üst olan bireyler de bulunmaktadır. İntihar eden bir vatandaşın yerde yatan halini sosyal ağlardan çekip görüntülemeyi ya da bir kız çocuğunun gözlerini önünde annesi ölmek üzereyken yardım etmeyi değil de görüntülemeyi seçmek kadar iletişim ve tepki verme halimizde değişiklikler yaşanmaktadır. Bireylerin medya ürünlerini tüketme alışkanlıkları da değişmektedir. Özellikle çalışma kapsamında, kadın kimliği üzerinden üretilen haberlere dikkat edildiğinde etik sorunların giderek daha da dikkat çekici hale gelmekte olduğu gözlenmektedir. 
Arslan H., Topal A. \& Dönük G. D. (2020). Türkiye'de Geleneksel Medya ve Yeni Medyada Kadın Kimliği Üzerinden Üretilen Haberlere Eleştirel Bakış. Dördüncü Kuvvet. 3 (1). 21-38

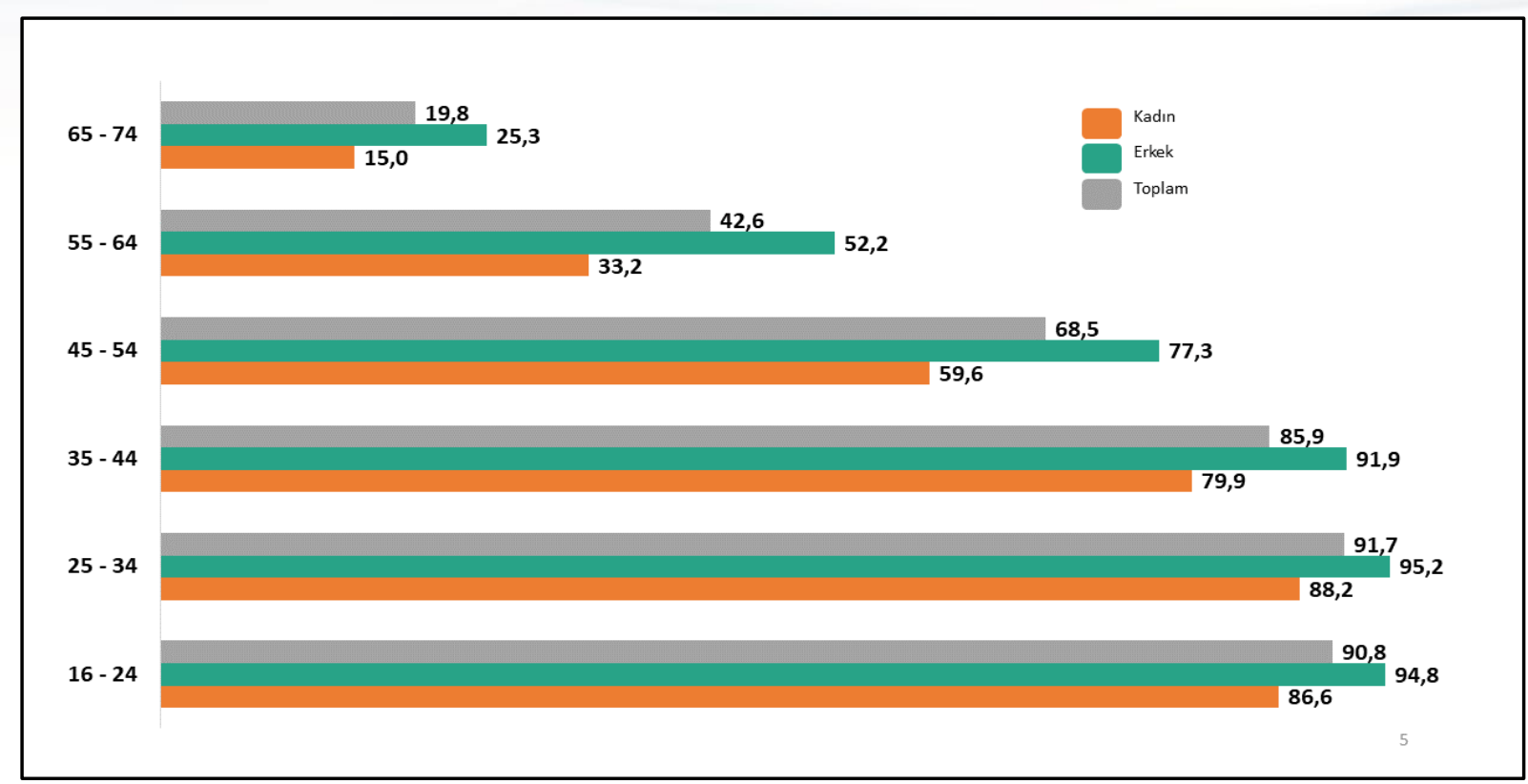

Şekil 3. Bireylerin Yaş Grubuna ve Cinsiyetine Göre İnternet Kullanım Oranları

Kaynak: https://dijilopedi.com/2019-tuik-hanehalki-bilisim-teknolojileri-kullanim-arastirmasi/Erişim Tarihi: 07.02 .2020

Yaşanan dönüşümlerle bireylerin mahremiyet ve gizlilik kavramlarının korunması oldukça zor durumdadır. Bazen bireylerin sosyal medyada özel fotoğrafları ya da videoları paylaşılabilmektedir. Bu özel alana müdahale ya da bu mecralardan bireyler üzerine yapılan hakarete yönelik paylaşımlar etik anlamda derinlemesine değerlendirme gereken konulardır.

\section{Kavramsal Çerçeve}

Tanımlar üzerinden başlamak gerekirse; en genel tanımıyla medya yığınlarla iletişimi sağlayan kitle iletişim araçları olarak tanımlanabilir. Geleneksel medya; yazılı ve görsel basın aracılığıyla olayların insanlara haber olarak duyurulduğu ve bu yolla iletişim kurulan bir ortamdır. (http://dijitalkulturgra331.blogspot.com/2013/01/yeni-medya-ve-geleneksel-medya-sunum.html.

Erişim Tarihi:07.02.2020)

Vural ve Bat yaptıkları çalışmada, yeni medya kavramının 1970'lerle birlikte bilgi ve iletişim tabanlı araştırmalarda, sosyal, psikolojik, ekonomik, politik ve kültürel çalışmalar yapan araştırmacılarla gündeme geldiğini belirtmişlerdir (Vural \& Bat, 2010: 3350).

Dilmen ve Öğüt de yeni ifadesinin kullanımında ve yaşanan dönüşümde özellikle vurgulanması gereken, altının çizilmesi gereken noktanın iletişim olgusu değil de iletişim ortamının kendisi olduğunu ifade etmişleridir. (Dilmen \& Ögüt, "Yeni İletişim Ortamları ve Etkileşime”e İletişimsel Bilişim Yaklaşımı, 2006) Genel olarak bakıldığında yeni medya ve geleneksel medyanın temel farkı etkileşimli ve multimedya biçemine sahip olması olarak aktarılmaktadır. (Binark, Yeni Medya çalışmalarında Yeni Sorunlar, 2007: 21)

Yeni medyanın sunduğu verilere, iletişim olanakları sayesinde istediğimiz anda ulaşabilmekteyiz. (Dilmen, Yeni medya kavramı çerçevesinde internet günlükleri-bloglar ve gazeteciliğe yansımaları, 2007: 115) Yeni medyanın geleneksel medyaya göre önemli bir farklıllı̆ı, ses, görüntü ve veri içeriklerini etkileşim öğesini de içerecek şekilde bir arada toplamasıdır (Aydoğan \& Kırık, 2012: 59). 
Arslan H., Topal A. \& Dönük G. D. (2020). Türkiye'de Geleneksel Medya ve Yeni Medyada Kadın Kimliği Üzerinden Üretilen Haberlere Eleştirel Bakış. Dördüncü Kuvvet. 3 (1). 21-38

Yeni medya ile geleneksel medya arasındaki farklar noktasında yeni medyanın, medya üretimi, dağıtımı ve kullanımı gibi oldukça geniş bir alan içerisindeki değişiklikleri de kapsadığı ve bu değişikliklerin de teknolojik, yazımsal, geleneksel ve kültürel alanı içerdiği değişiklikler olduğu ifade edilebilir (Kılınç \& Kilınç, 2014: 11).

Geleneksel medyada sabit bir bilgi akışı mevcutken yeni medyada, kullanıcı medyanın sundukları ile içerik üzerinde ilk önce hâkimiyet kurarken, sonrasında etkileşime girer ve bunu yeni bir deneyime çevirir (Yanık, 2016: 907).

Yeni iletişim teknolojileri bireylerin yaşam pratiklerinin içerisine o kadar eklemlenmiş durumdadır ki Altunay yeni dönem içerisinde geleneksel medya kullanıcıları ile yeni medya kullanıcıları arasındaki farkı aktarırken eskiden görme ve işitme duyuları ile yaşanan sürecin içerisine dokunma duyularını da dâhil etmeye başladıkları bir süreci yaşadıklarını belirmiştir (Altunay, 2012: 43).

\begin{tabular}{|l|l|l|}
\hline \multicolumn{2}{|c|}{ Geleneksel Medya } & \multicolumn{1}{c|}{ Yeni Medya } \\
\hline Kanal & Az sayıda & Çok sayıda \\
\hline Kontrol & Gönderen & Alıcı \\
\hline İletim & Tek yönlü & İki yönlü, etkileşimli \\
\hline İçerik & Sinırlı & Çeşitlendirilmiş \\
\hline Kapsama Alanı & Bölgesel, küresel & Küresel \\
\hline Toplumsal Kontrol & $\begin{array}{l}\text { Kanunlar, meslek ve ahlâk } \\
\text { ilkeleri, halk eğitimi }\end{array}$ & Teknik aygıtlar, izleme \\
\hline Zaman & Senkron & Asenkron \\
\hline Yapısı & $\begin{array}{l}\text { Merkeziyetçi (bir noktadan-çok } \\
\text { noktaya) }\end{array}$ & $\begin{array}{l}\text { Merkeziyetçi olmayan (çok } \\
\text { noktadan-çok noktaya }\end{array}$ \\
\hline
\end{tabular}

Tablo 1. Yeni Medya ile Geleneksel Medya Arasındaki Farklılıklar (Aktaş, Yeni Medyanın Geleneksel Medya ile Karşılaştırılması, 2007)

Yeni medya ve geleneksel medya arasındaki farklar;

-Dijitallik

- Etkileşimsellik,

-Multimedya biçimselliği,

- Hipermetinsellik,

-Kullanıcı türevli içerik üretimi,

-Yayilım,

-Sanallık şeklinde sıralanabilir. (Binark \& Bayraktutan, Ayın Karanlık Yüzü Yeni Medya Ve Etik, 2013: 19)

İnternetin ardından sosyal ağların hayatımızın içerisinde bu kadar yer alması medyanın işlevinin ve işleyişinin değişime uğramasını sağlamıştır. (Sözeri, 2012: 281) Kuyucu yaptığı çalışmada geleneksel medya ile yeni medya arasındaki farklılıkları ve aradaki dönüşümü aktarmıştır. Buna göre Kuyucu; geleneksel gazetecilik anlayışı içerisinde nitelikli haber yapmanın ve tiraj yakalamanın önemli olduğunu, sosyal medya ile birlikte gazetelerde nicelliğin önem kazandığını belirtmiştir. Ayrıca yeni iletişim teknolojilerinin geleneksel gazeteciliğin dönüşüme uğramasındaki en önemli etken olduğunu da ifade etmiştir. (Kuyucu, 2016: 447-449)

Yeni medyada yer alan haberlerde bireyler daha fazla içeriğe ulaşabilmektedir. Haberlerin geleneksel medyaya oranla daha geniş olarak zaman kavramı ortadan kalkmış şekilde işlenmesi, artıları yanında negatif tarafları da barındırmaktadır. Haber üretiminde bireylerin geleneksel medya içerisinde sadece 
Arslan H., Topal A. \& Dönük G. D. (2020). Türkiye'de Geleneksel Medya ve Yeni Medyada Kadın Kimliği Üzerinden Üretilen Haberlere Eleştirel Bakış. Dördüncü Kuvvet. 3 (1). 21-38

tüketen konumundan üreten konuma geçmesi beraberinde bu mecraların doğruluk, güvenilirlik, gizlilik, mahremiyet kavramlarını nasıl kullandığı sorunsalını da getirmektedir.

Genel'in de ifade ettiği gibi yeni medya bir kuralsız ve tırnak içinde özgürlüklerle ş̧ekillenmiş ve kısmi hukuki düzenlemelerle habere yön verilen ve şekillendirilen bir sistem olarak karşımızda durmaktadır (Genel, 2016: 13). Yeni iletişim teknolojilerinin sunduğu olanaklar ile haber yapım ve üretim sürecinde, habercilik pratikleri bağlamında da değişiklik söz konusudur (Yurdigül \& İspir, 2015: 62).

Kullanıcılar yeni medya ortamında içeriğin büyük kısmını kendileri oluşturmaktadırlar. (Aktaş, Yeni Medyanın Geleneksel Medya İle Karşılaştırılması, 2007: 7) yeni medyada habere ya da bilgiye ulaşmak geleneksel medyada olduğundan çok daha kolaydır. Sunulan ya da aktarılan içerik kadarıyla yetinmek, haber için ayrılan alan veya saatleri beklemek durumunda kalan kullanıcı yeni medya ile birlikte geri bildirimi anlık olarak gerçekleştirebilmekte, içeriğe istediği an ve yerde ulaşabilmekte hatta içeriği bile oluşturabilmektedir. Bu kadar etkide bulunduğu bir alanın artık etik anlamda kontrolden çıkmaya başladığı gözlenmektedir. Bu durum pek çok alanda kendisini belli ederken çalışma kapsamında kadın kimliği üzerinden üretilen haberlerin özellikle kadın cinayetlerinin sunumu noktasında siklıkla yaşandığı ortadadır. Geleneksel medya ve yeni medya açısından konu değerlendirildiğinde her iki alanda da kadın kimliği üzerinden yapılan haberler genel olarak incelendiğinde kadın evin hanımı, yemek yapan, temizlik yapan, alışveriş tutkunu, çocuk bakan, saç, makyaj, diyet üzerine konu olabilecek kimlik ya da rollerde habere ya da sunuma konu olmaktadır. Geleneksel medyada sunulan içeriğin yer ve zaman kısıtı yeni medyada bulunmamaktadır, bu durum da haber içeriğinin ayrıntılı paylaşımını, görsellerin detaylı kullanımını sağlamaktadır. Kimi durumlarda faydalı olabilecek bu paylaşımlar bazen etik anlamda ihlalleri beraberinde getirebilmektedir.

Yeni medyada yer alan haberlerin meslek etiğine uygunluğu, haberin kaynağı, güvenilirliği, doğruluğu denetlenmesi son derece büyük önem taşımaktadır. Üretilen haberlerin toplumun psikolojik yapıs1 üzerine etkisinin, toplumda birbirine karşı taşıdığ1 güven duygusu ve birlik beraberlik duygusunun korunması bağlamında dikkat edilmediği takdirde geriye dönülmez sıkıntılar oluşturabilecektir. Bu gibi sebeplerle geleneksel medya içerisinde de yeni medyada da haberlerin süzgeçten geçirilmesi, editoryal çalışmaların özenle gerçekleştirilmesi oldukça önemlidir. Medya haberi halka, okuruna ya da takipçisine ulaştırmak için haber peşinde koşarken halk da bilgilenmek ve bu en doğal hakkını kullanmak istemektedir. Özellikle toplumun içinden geçtiği zor zamanlarda olayları siyasal boyuta taşıma gibi habere ulaşma, haber edinme hakları medya kuruluşları açısından ne kadar önemli ise habere konu olan kişi, kişiler, aileler, kurum ya da kuruluşların da hakları, özgürlükleri hem yasal bağlamda hem de etik açıdan önemsenmelidir. Bazen medya kuruluşlarının habere konu olanların haklarına yönelik etik ihlalleri gözlenebilmektedir. Denetim mekanizmaları yeni medya içerisinde işlerliğini çok da gösterememektedir. Aslında bu pek de kolay bir durum değildir. Yasal düzenlemeler ve kontroller yapılması için gerekli adımların atılması çok fazla çalışmayı gerektirmektedir.

Etik kavramı, Türk Dil Kurumu güncel sözlükte; çeşitli meslek kolları arasında tarafların uyması veya kaçınması gereken davranışlar bütünü ve ahlak şeklinde tanımlanmıştır. (https://sozluk.gov.tr/?kelime=siyasal\%20etik) Geleneksel medya ile yeni medya arasındaki farkların en belirgin özelliklerinden bir tanesi de tüketici gibi görülen kullanıcıların anında geri bildirimde bulunabilmeleridir. Medya kullanıcıları, bazen haberin, direkt olarak yaptığı kayıtlar ile üreticisi de olabilmektedir. Medyanın mesleki etik boyutu tartışılırken bu nokta önemini artırmaktadır. Yeni medyada etik anlamda yaşanan sorunlar arasında telif hakkı, reklam kullanımı, özel hayatın gizliliği ihlali, dolandırıcılık bu kişisel verilerin korunması kapsamında değerlendirilmelidir, nefret söylemi, cinsiyet ayrımcılığı, görsel paylaşımı gibi konular olarak sayılabilirken bu örnekler daha da artırılabilir.

İrvan medya etiği dendiğinde medya organının kendisinin etik ya da etik dışı diye değil medya organında çalışanların böyle bir değerlendirilmeye tabi tutulması gerekliliğinden bahsetmektedir yani gazetecilerin etiğinden söz etmek gerekliliğine vurgu yapmaktadır (İrvan, 2003: 52). 
Arslan H., Topal A. \& Dönük G. D. (2020). Türkiye'de Geleneksel Medya ve Yeni Medyada Kadın Kimliği Üzerinden Üretilen Haberlere Eleştirel Bakış. Dördüncü Kuvvet. 3 (1). 21-38

Bu noktadan bakacak olursak, yeni medya özellikle sosyal medya, hemen herkesin içerik üretimi ile yer aldığı bu denetimsiz mecrada, bu mesleği profesyonel olarak yapmayanların da bir gazeteci gibi yaptıkları paylaşımlar da denetimi zorlaşacaktır.

Sosyal medyada yer alan her içeriğin, bilginin, görselin doğruluğu, kaynağı, güvenilirliği etik anlamda tartışılacak konulardır. Çünkü yeni iletişim teknolojilerinde yığın halinde gelen enformasyon, kitle iletişim araçlarına ulaşımın kolaylığı, bilgiye erişim olanaklarının artmasıyla beraber bu mecraların da güvenilirliği sorgulanmaya başlanmıştır. Sosyal medyada bireyleri karalayıcı, iftira, hakaret edici, tacizler gibi olumsuz durumlarla da karşılaşılmaktadır. Ünlülere yapılan tacizler yanında genç bir kıza erkek arkadaşı tarafindan sosyal medya üzerinden gönderilen tehdit içeren mesajlar ya da siber zorbalığa kadar pek çok durumla karşılaşılmaktadır.

Geleneksel medyada işlenen bir haber, sınırlı oranda sunulurken yeni medyada yer ve zaman sıkıntısı olmadan sunulabilmektedir. Özellikle yeni medyada reyting uğruna kadın kimliğinin haberlerde sunumunda etik kurallara dikkat edilmediği gözlenmektedir. Bu noktada söylenmesi gerekenlerden bir tanesi yeni medya ile birlikte üretilen haberlerin gazetecilik kimliği yanı sıra bu meslekle ilgisi olmayan kişilerin de haberlerin üretim sürecinde yer alıyor olmalarıdır. Bu durum etik kuralların dikkatle uyulması gereken bir meslekte aslında yeni teknolojilerle var olan sorunların üzerine farklı sorunlar eklemektedir. Anlık haber iletimi, yer probleminin olmamas1, zaman sıkıntısını ortadan kaldırması açısından yeni medyanın geleneksel medya içerisinde yaşanan etik problemleri artırdığı düşünülebilir. Tüm bu etik problemlerin tamamıyla yeni medya ile ortaya çıktığı söylenemez. Zaten mevcut olan problemler yeni medya ile birlikte boyut atlayarak devam etmektedir. Buradaki sıkıntılar, yaşanan bir kadın cinayetinde verilen haberin geleneksel medyada sunumunda yaşanan sıkıntılarla, yeni medyada cinayetin aktarıldığı bireylere orada yaşıyormuşçasına, içerisinde seyirci haline getirmesinden kaynaklanmaktadır.

Öztürk yaptığı çalışmada sosyal medya yaşanan etik sorunları maddeleştirmiştir. Buna göre ihlaller şu şekilde sıralanabilir;

- Özel yaşamın gizliliği,

- İçeriğin asıl kaynağının gösterilmemesi,

- Telif/patent hakları,

- Üretilen içeriklerin olgunlaşmadan ve doğrulanmadan yayılması,

- Kişisel veri güvenliğinin sağlanamaması,

- Veri madenciliği,

- Dijital gözetim olgusu,

- Haber ve ticari enformasyonun sınırlarının belirsizleşmesi,

- Fazla reklam yer almas1,

- Kullanıcıyı yanıltacak etiketleme ve başlıklandırma,

- Nefret söyleminin varlı̆̆

- Bireyin tüketici olarak alınmasi,

- Genel ahlaka aykırı içerik oluşturmak ve yaymak,

- Anonimlik olgusu,

- Trol olgusunun görünmesi (spam blog),

- Dil (Öztürk, 2015: 299-304)

Gelişen ve değişen iletişim teknolojileri ile birlikte gazetecilik ya da haber pratiklerinde de değişim yaşandığı gözlenmektedir. Bu değişim özellikle kendini haber üretim sürecinde göstermektedir. Geleneksel ve yeni medyada kadın kimliği üzerinden üretilen haberler incelenen haber başlıkları ele alınarak değerlendirildiğinde haberlerin genellikle tiraj kaygısı gözetilerek yapıldığı, magazin malzemesi olarak kullanıldığı gözlenmektedir. Geleneksel medyadan farklı olarak yeni medyada bu noktadaki farklılıklar içeriklerin daha detaylı bir şekilde aktarılmasıdır. Geleneksel medyada da kadın evinde, anne, eş kimliğiyle yerini almakta aynı şekilde yeni medyada da kadın, eş, anne, güzel 
Arslan H., Topal A. \& Dönük G. D. (2020). Türkiye'de Geleneksel Medya ve Yeni Medyada Kadın Kimliği Üzerinden Üretilen Haberlere Eleştirel Bakış. Dördüncü Kuvvet. 3 (1). 21-38

kimliğiyle sunulmaktadır. Sadece belirtildiği gibi aradaki fark, kadın kimliği olarak aynı kalsa da üretilen haber içerikleri artık daha fazla okunmaya olanak sağlayacak şekilde, içerik doldurmaya müsait araçlar ve olanaklarla desteklenir durumda olmasıdır. Hem geleneksel medyada hem de yeni medyada kadın olmak hep aynı ortak noktada buluşmaktadır: Kadın, iş hayatında aktif üretici kimlikte daha nadir, geleneksel anlamda biçilmiş rollerde daha fazla yer almaktadır.

Yeni medya, sahip olduğu etkileşimsellik, multimedya biçemselliği, hipermetinsel yapısı ve dijital kodlama özelliğiyle enformasyonun üzerinde oldukça etkilidir ve internet gazeteleri enformasyon araçlarının en önemlilerinden biridir (Söğüt, 2019: 214).

Yeni medya aracılı̆̆ıyla sunulan haberleri insanlar, geleneksel medyadan öğrenecekleri haberlere göre daha ayrıntılı, daha yaşar gibi anın içinde olurcasına ve anlık olarak öğrenebilmekte bunun yanında duygularını, düşüncelerini de anlık olarak aktarabilmektedirler. Geleneksel medya ve yeni medya içerisinde kadının yer alış biçimleri sıklıkla araştırma konusu yapılmaktadır. Kadın toplumsal yapı içerisindeki rolleri ile sosyal, beşerî alanlarda değerlendirilmiştir. Hep de değerlendirilecektir. Yeni medya aracılığıyla duyurulabilirlik daha da artmıştır. Görünür olmak, beğenilmek, gözlemek, gözetlemek ifadeleri yeni medya ile daha da artmıştır. Görünür olmaya çalışırken arkamızda bıraktığımız sosyal ayak izimiz ya da dijital ayak izimiz bizden sonra da varlığını sürdürmektedir. Yeni medya ile toplumsallaşmanın önemli boyutlarının işlevsel kılındığı ve gelişen teknoloji ile birlikte ivme kazandığı görülmektedir (Çambay, 2015: 243).

Kadın genel olarak güzellik, estetik, ince vücut ölçüleri, makyaj, saç, bakım, modaya uygunluk gibi unsurlarla donatılarak, bu unsurlara uyan rollerle bütünleştirilmiştir (Uğurlu, 2015: 244). Kadınlar aldatılan, aldatan, kurban, diyet yapan, yemek tarifi alan, ev temizleyen, iyi bir eş, arada siyasal aktör arada sportif faaliyetlerde yer alan olarak konumlanmaktadır. Genellikle erkek egemen bakış açısıyla sunulan haberlerin kadın kimliği üzerinden yapılan içeriklerde genel olarak bu konular üzerinden gidilmektedir. Sadece geleneksel medyada yer alamayan ancak yeni medyada yer alan bir farklılık kadınların kendi ürettikleri haberlerin içerisinde konumlanmış olmalarıdır. Kadınlar girişimci olarak yer aldıkları yeni medya içerisinde sosyal ağlarda varlıklarını bloglarda sürdürmektedirler.

Sosyal medyada yer alan haberlerde etik konusunun detaylı bir şekilde ele alınıp gazetecilik çalışmaları açısından herkesin bir haber üretme peşinde olduğu günümüzde detaylıca ele alınıp düzenlenmesi gerekmektedir.

Emine Bulut cinayetinde yaşanan olayın içeriği kaydedip paylaşan, annesi gözünün önünde can çekişen bir çocuk, canını kurtarmaya çalışan bir kadın, karısını katleden adam tarafı gibi birçok boyutu bulunmaktadır. Tüm bunlar geleneksel medya ile yeni medyada kadın kimliği üzerinden haberlerin sunum detayları açısından farklılıklar göstermektedir. 
Arslan H., Topal A. \& Dönük G. D. (2020). Türkiye'de Geleneksel Medya ve Yeni Medyada Kadın Kimliği Üzerinden Üretilen Haberlere Eleştirel Bakış. Dördüncü Kuvvet. 3 (1). 21-38

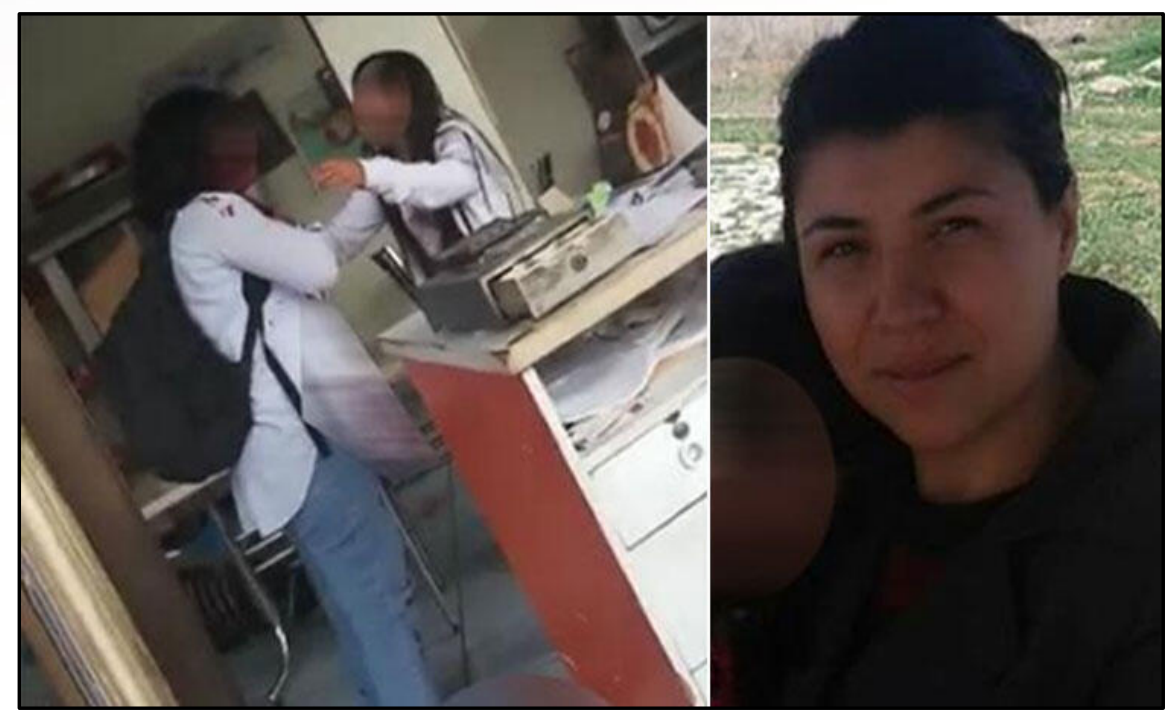

\section{Fotoğraf 1.}

Kaynak: https://www.hurriyet.com.tr/gundem/fedai-varanin-avukati-emine-bulutolmeden-yarim-saat-once-karakola-sigindi-ama-kolluk-kuvvetleri-onu-koruyamadi41346976. Erișim Tarihi: 07.02.2020

Emine Bulut olayında yaşananlar sosyal medya kullanıcılarının, haber uğruna yapabildikleri noktasında en uç örneklerden biridir. Kızının gözlerinin önünde ölmek istemiyorum diye haykıran bir annenin feryadına yanıt vermek yerine bunu görüntülemeyi tercih eden bir zihniyetin, yeni medya kullanıcılarına bu tarz içeriklerin paylaşımına yönelik acil bir kullanım kontrolü sağlanması gerekliliğini gözler önüne sermektedir. Bu olayda yapılan haberde ayrıntıların çok açık bir şekilde topluma sunulması, toplumsal bir travma oluşturabilecek durumdadır. Haber içeriklerinin yanında sosyal medya yoluyla yaşanan olaylar karşısında yapılan çok farklı yorumlar da aslında farklı bir çalışma konusu oluşturabilecek, belirtilmesi gereken bir noktadır. Bu olayda da görüldüğü üzere bunun gibi yaşanan daha pek çok olayda bazı sosyal medya kullanıcıları, olaylara karşı neredeyse şiddeti meşrulaştırmaya yönelik tutum sergilemektedirler. Yeni medya kullanıcılarına kendi kimliklerini olduğu gibi aktarmadan farklı anonim kimlikler altında dilediği yorumu yapabilme imkânı sağlamaktadır.

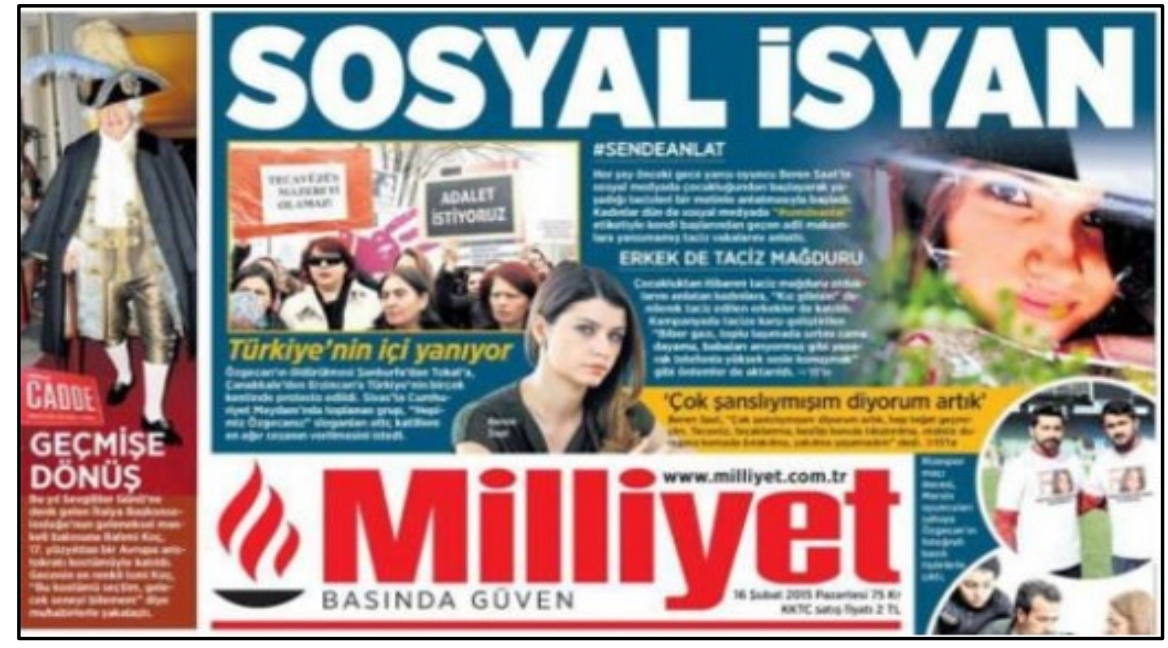

Fotoğraf 2. Anaakım medyada kadın cinayetlerine ilk sayfadaki bakış açısına örnek.

Kaynak: https://www.cnnturk.com/fotogaleri/turkiye/gazete-mansetleri-16-subat2015? page =24 Erişim Tarihi: 20.02.2020 
Arslan H., Topal A. \& Dönük G. D. (2020). Türkiye'de Geleneksel Medya ve Yeni Medyada Kadın Kimliği Üzerinden Üretilen Haberlere Eleştirel Bakış. Dördüncü Kuvvet. 3 (1). 21-38

Geleneksel medyada, toplumu bu denli yaralayan bir olayın sosyal medyada oluşturduğu etki de vurgulanmaktadır. Yaşanan teknolojik gelişmeler ve iletişim teknolojisindeki ilerlemelerin geleneksel medyayı yok ettiğini değil de dönüştürdüğünü söylemek daha doğru bir ifade olacaktır. Sosyal medya burada görüldügü gibi toplum vicdanında önemli aşamalardan geçildiği dönemde, zor zamanlarda doğal afet, savaş gibi bireyleri tek vücut olmaya, birleştirici, bütünleştirici bir mecra olmaya yöneltebilmektedir.

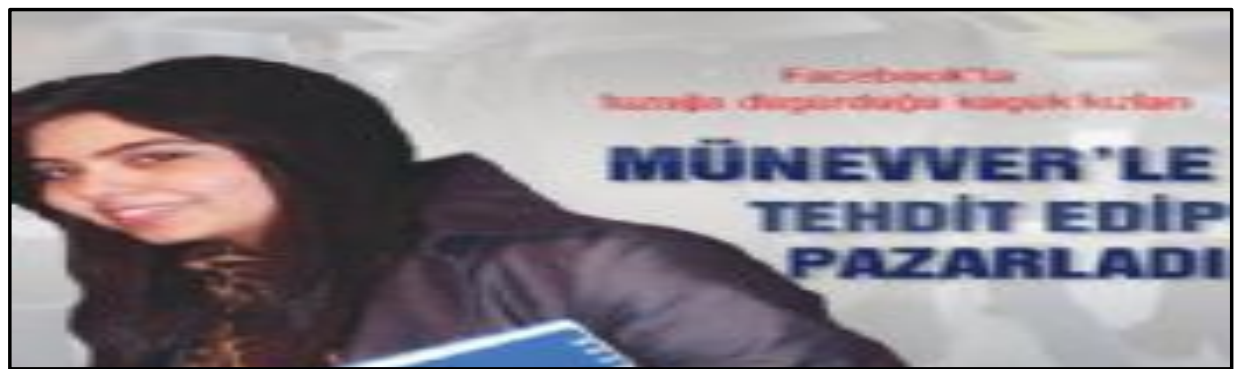

Fotoğraf 3. “Küçük kızları 'Münevver'le tehdit edip pazarladı. Facebook'ta tuză̆a düşürdüğ̈̈ küçük yaştaki kızları Münevver Karabulut'la tehdit edip, önce tecavüz etti sonra pazarladl."

Kaynak: http://beyazgazete.com/haber/2011/12/29/kucuk-kizlari-munevver-le-tehditedip-pazarladi-765720.html. Erişim Tarihi:21.02.2020

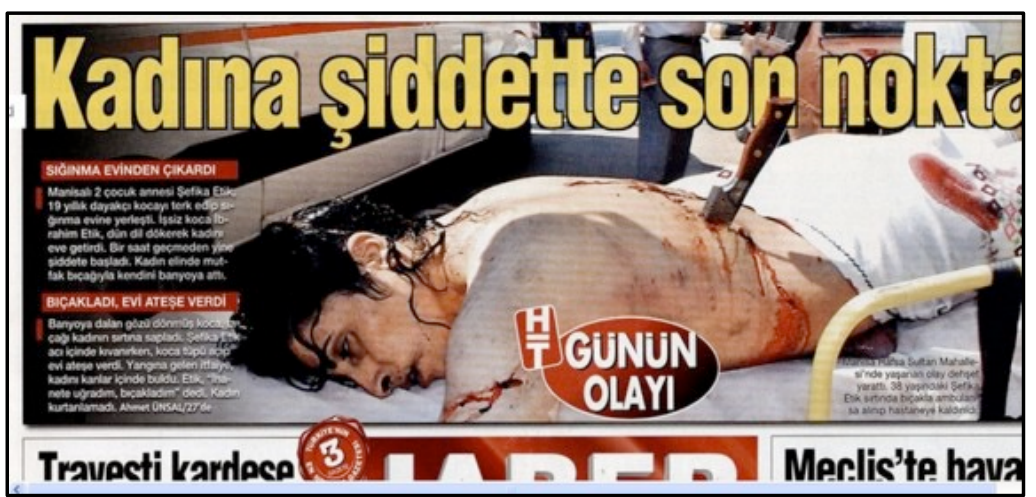

Fotoğraf 4. Habertürk Gazetesi Kadın Cinayeti Görseli

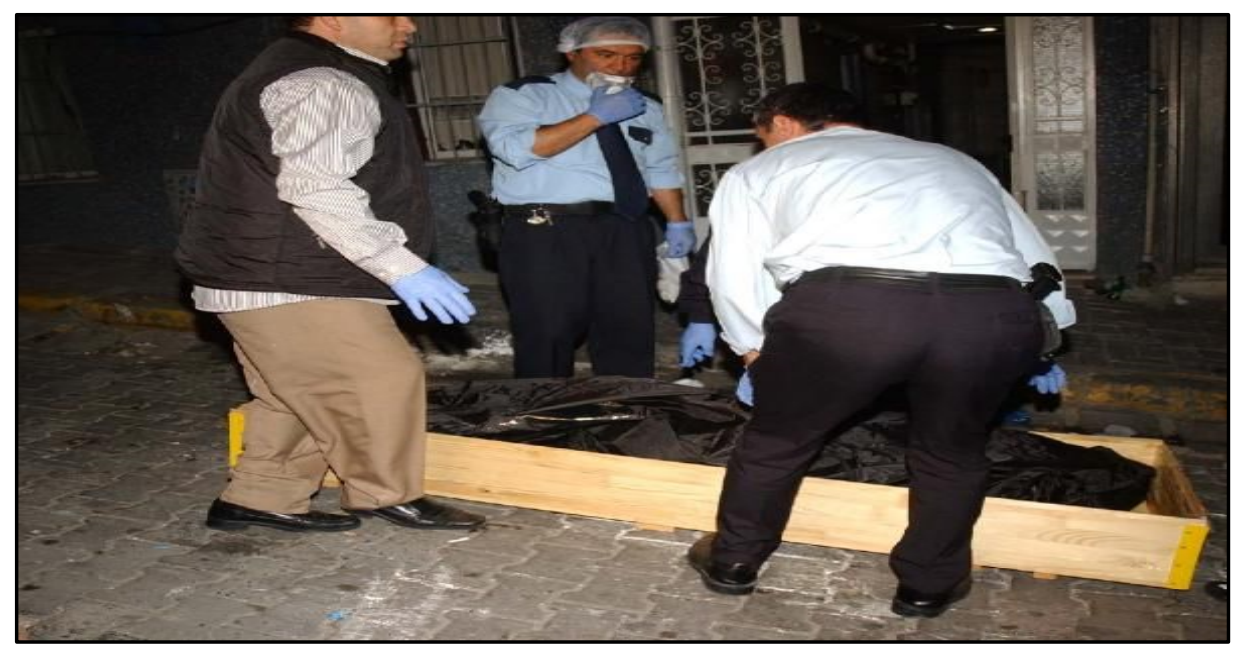

\section{Fotoğraf 5.}

Kaynak: "https://www.sondakika.com/haber/haber-yenibosna-da-vahset-universiteli-genc-kizyari-4013598 Erişim Tarihi: 11.02.2020 
Arslan H., Topal A. \& Dönük G. D. (2020). Türkiye'de Geleneksel Medya ve Yeni Medyada Kadın Kimliği Üzerinden Üretilen Haberlere Eleştirel Bakış. Dördüncü Kuvvet. 3 (1). 21-38

Üniversite öğrencisi Fatma Nur Çelik'in öldürülmesine ilişkin haber detayları yine geleneksel ve yeni medyada benzer şekilde ele alınmış ancak aradaki fark yeni medya olanakları içerisinde haberin zaman ve yer sıkıntısı olmaması nedeniyle detaylı, çok ayrıntılı bir şekilde sunulmuş olmasıdır. Bunun yanı sıra bu olaya ilişkin olarak Fatma Nur Çelik'in yarı çıplak bedeninin Habertürk Gazetesi'nin web sayfasında sunulması ve bunun ardından fotoğrafın sosyal medyada da paylaşılmış olması yeni medya gibi bir alanın haberlerin yayılım hızı ve kolaylığı açısından nasıl bir alan olduğunu gösterir niteliktedir. Konuyla ilgili olarak internet sitelerinden de paylaşılan görsel ve içeriklerle ilgili kınama mesajları yayınlanmıştır (http://medyatakipbulusankadinlar.blogspot.com/2012/10/bir-medya-ahlakszlg-ornegiolarak.html)

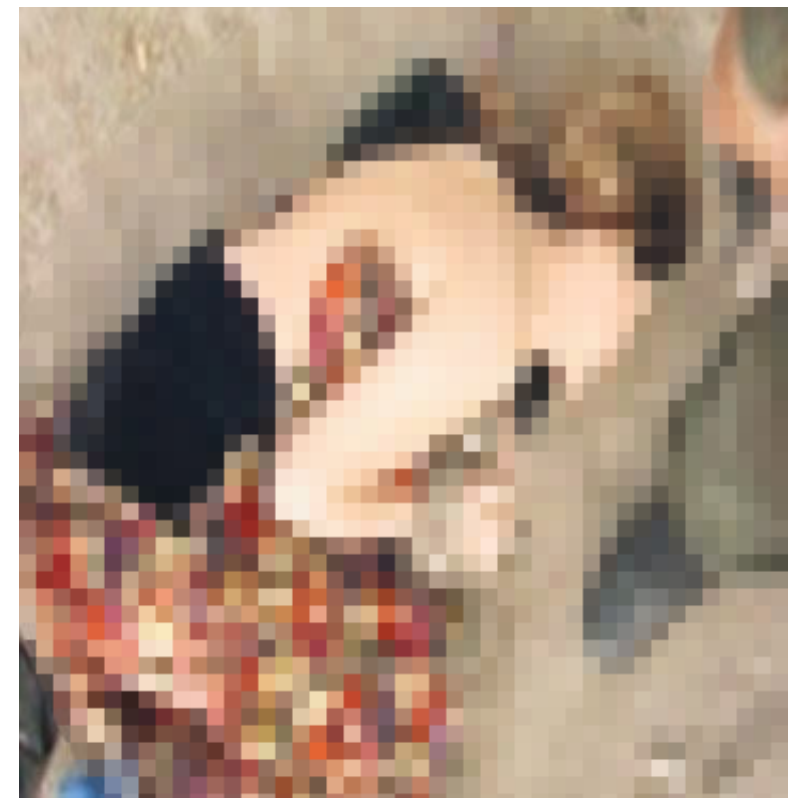

Fotoğraf 6. Bir medya ahlaksızlı̆̆ı örneği olarak HaberTürk Kaynak: https://www.haberturk.com/haberleri/fatmanurcelik- Erişim Tarihi:11.02.2020

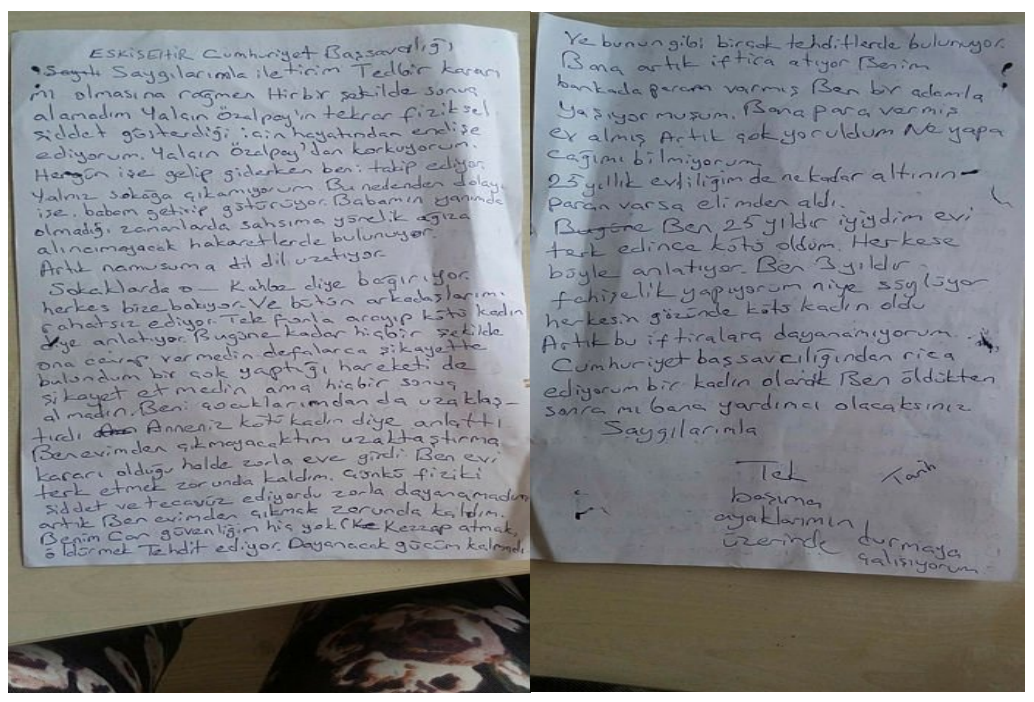

Fotoğraf 7. "Eşsi tarafindan vahşice öldürülmüştü! Ayşe Tuba Arslan'ın yeni şikâyet dilekçesi ortaya çıktı!”

Kaynak: https://www.takvim.com.tr/yasam/2019/12/02/esi-tarafindanvahsice-oldurulmustu-ayse-tuba-arslanin-yeni-sikayet-dilekcesi-ortayacikti Erişim Tarihi: 11.02.2020 
Arslan H., Topal A. \& Dönük G. D. (2020). Türkiye'de Geleneksel Medya ve Yeni Medyada Kadın Kimliği Üzerinden Üretilen Haberlere Eleştirel Bakış. Dördüncü Kuvvet. 3 (1). 21-38

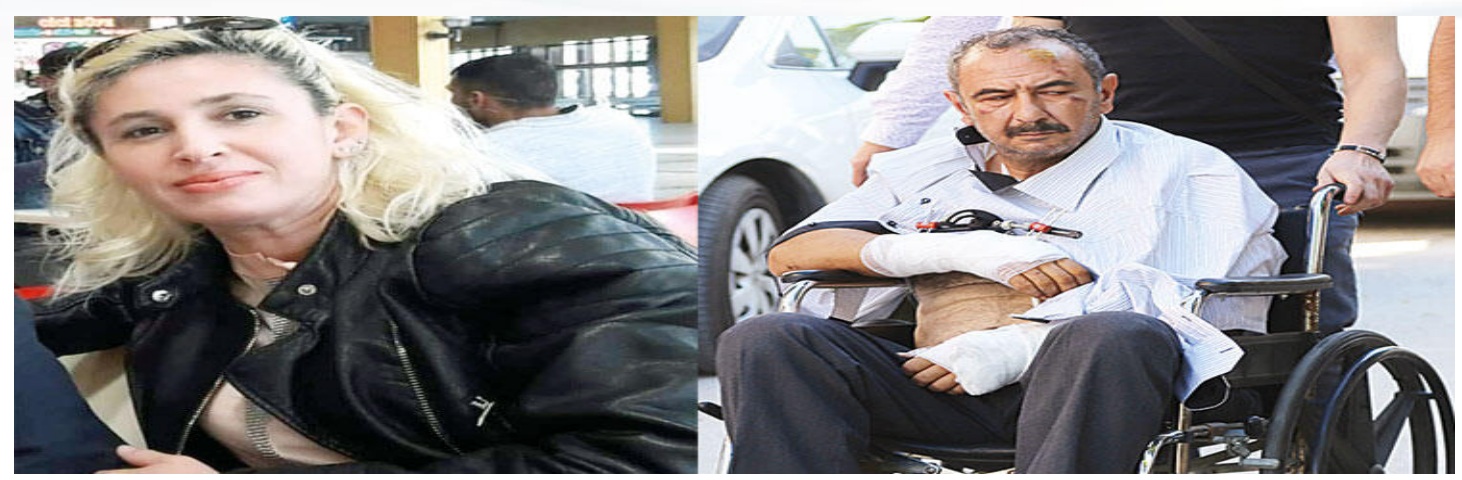

Fotoğraf 8. "Gözaltına alındı, başka suçu yok diye serbest bırakıldı!”

Kaynak: https://www.hurriyet.com.tr/gundem/gozaltina-alindi-baska-sucu-yok-diye-serbest-birakildi41388871_Erişim Tarihi: 18.02.2020

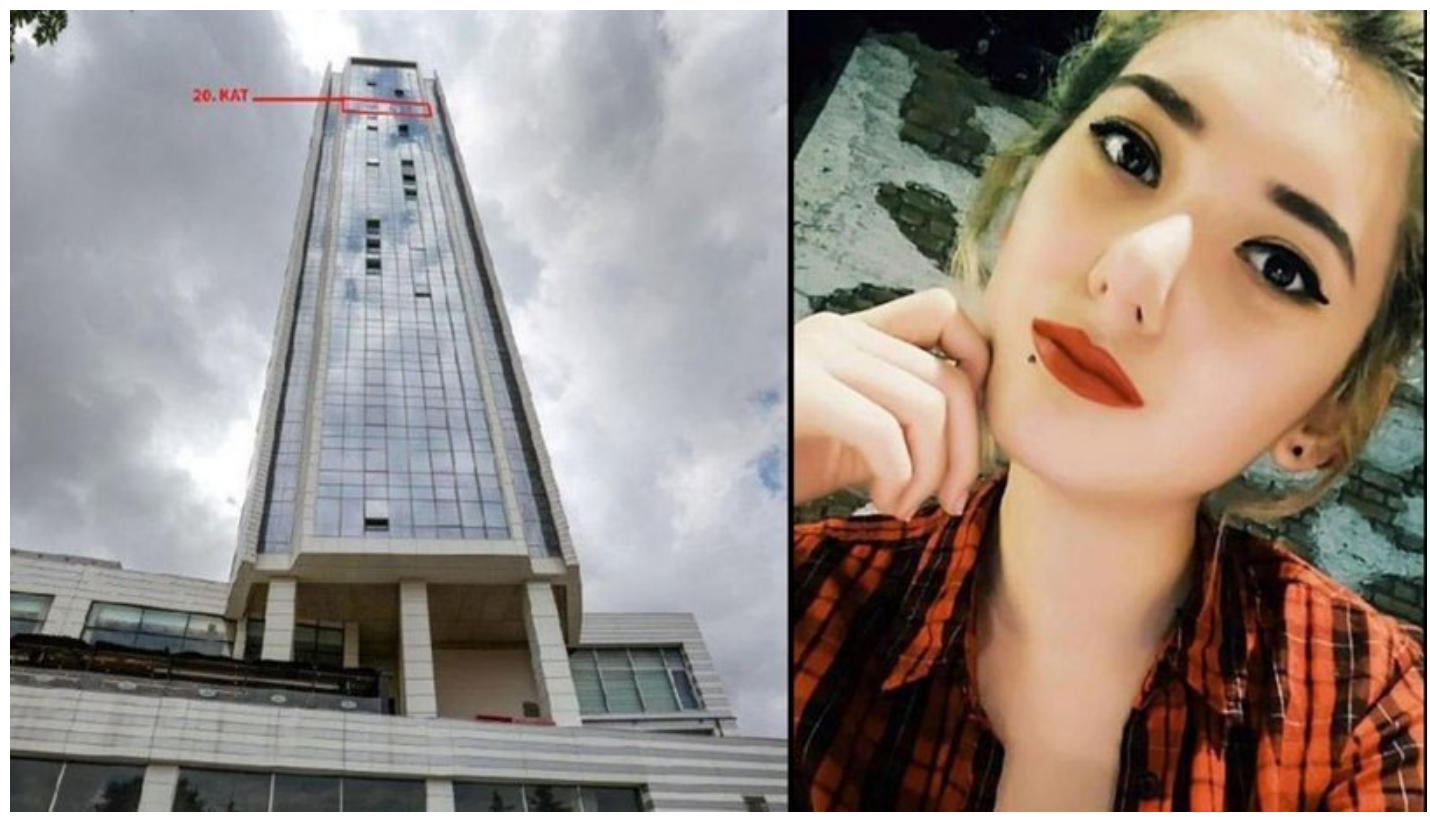

Fotoğraf 9. "Şule Çet'in Ölümüyle İlgili Davada Kan Donduran Beyan: Cinsel Zorlama Var"

Kaynak: https://www.haberturk.com/sule-cet-in-olumuyle-ilgili-dava-cinsel-zorlama-var-2503178-

Erişim Tarihi: 18.02 .2020 )

Şule Çet davası da yine internet gazeteciliği ile tüm detayları ile geleneksel medyaya göre oldukça ayrıntılı bir şekilde aktarılmışıı. Burada belirtilmesi gereken, aslında her iki mecrada kadın kimliği üzerinden üretilen haberlerde kullanılan dilin hemen hemen aynı görünmesidir. Yani seçilen kelimeler vahşet, dehşet, kan donduran, vahşice gibi şiddet unsurlarını direkt olarak ifade eden kelimelerdir. Görseller de aynı şekilde oldukça ayrıntılı, şiddete etik açıdan değil de tiraj bakımından yaklaşan unsurlar olarak sunulmaktadır. Yukarıda Şule Çet haberinde verilen görselde 26. katın yüksekliğini okura aktarabilmek için çekim açısı ayarlanmıştır. Elbette habercilik okura doğru bilgiyi, enformasyonu, gerçekleri, olayları aktarabilmektir. Ancak bunları gerçekleştirirken olayın içerisinde bulunan kişilerin ya da bu kişilerin yakınlarının yaşayacakları travmalar düşünülerek, etik açıdan değerlendirmeler yapılarak aktarılmalıdır. Sunulan bilginin içerisinde yer alan kişi kendi yakını olsaydı ya da kendisi olayda haber içeriğinin sunumuna yaklaşımı kendisini nasıl bir psikolojik çıkmazın içerisine sokacaktı sorusuna verilebilecek cevap sadece haberciler için değil, yeni medyanın tüm kullanıcıları için değerlendirilmesi gereken bir noktadır. 
Arslan H., Topal A. \& Dönük G. D. (2020). Türkiye'de Geleneksel Medya ve Yeni Medyada Kadın Kimliği Üzerinden Üretilen Haberlere Eleştirel Bakış. Dördüncü Kuvvet. 3 (1). 21-38

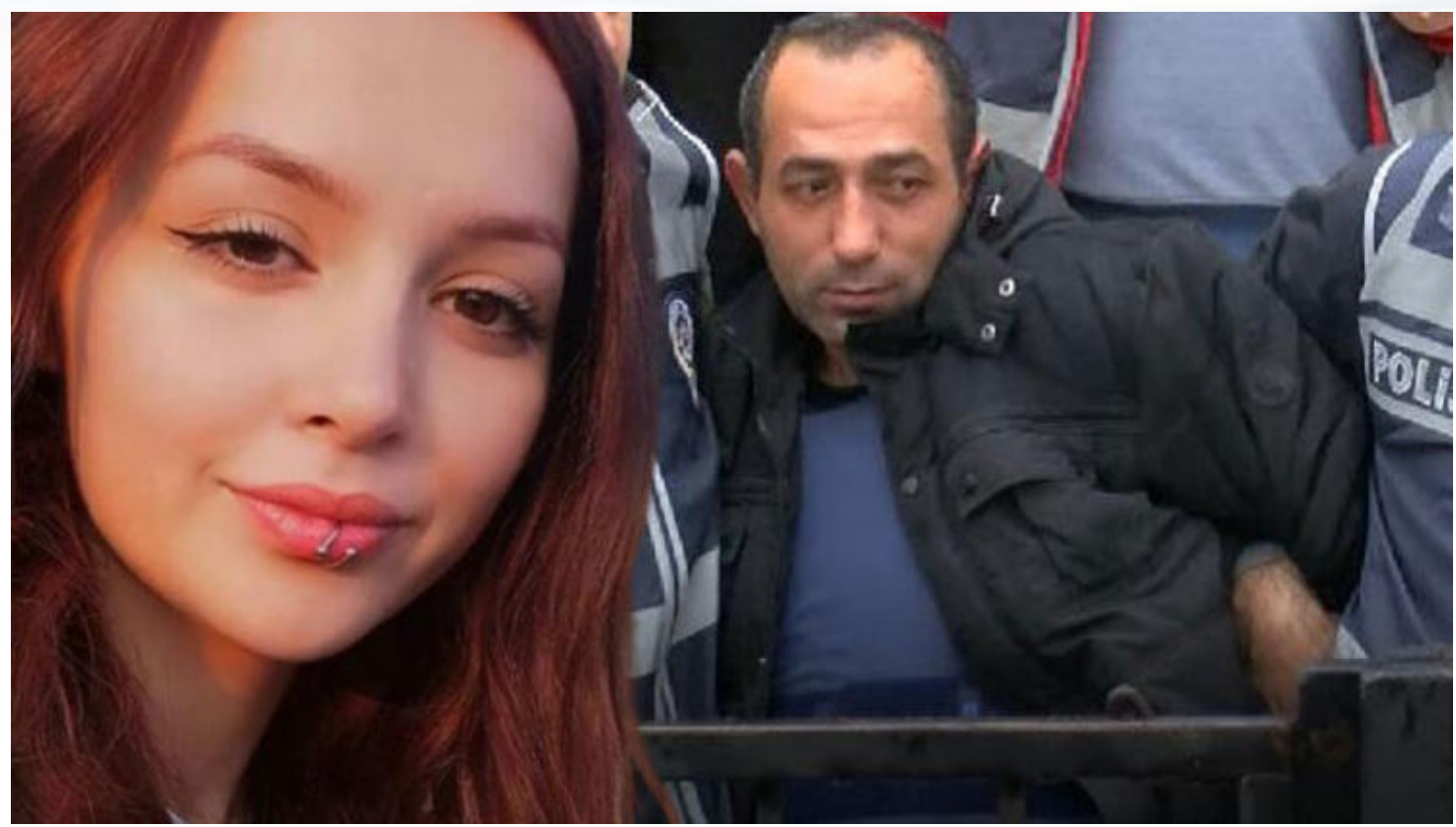

Fotoğraf 10. "Ceren Özdemir'i öldürmüşs olmak için öldürdü!’”

Kaynak: https://www.hurriyet.com.tr/gundem/oldurmus-olmak-icin-oldurdu-4144610 Erişim Tarihi: 18.02.2020

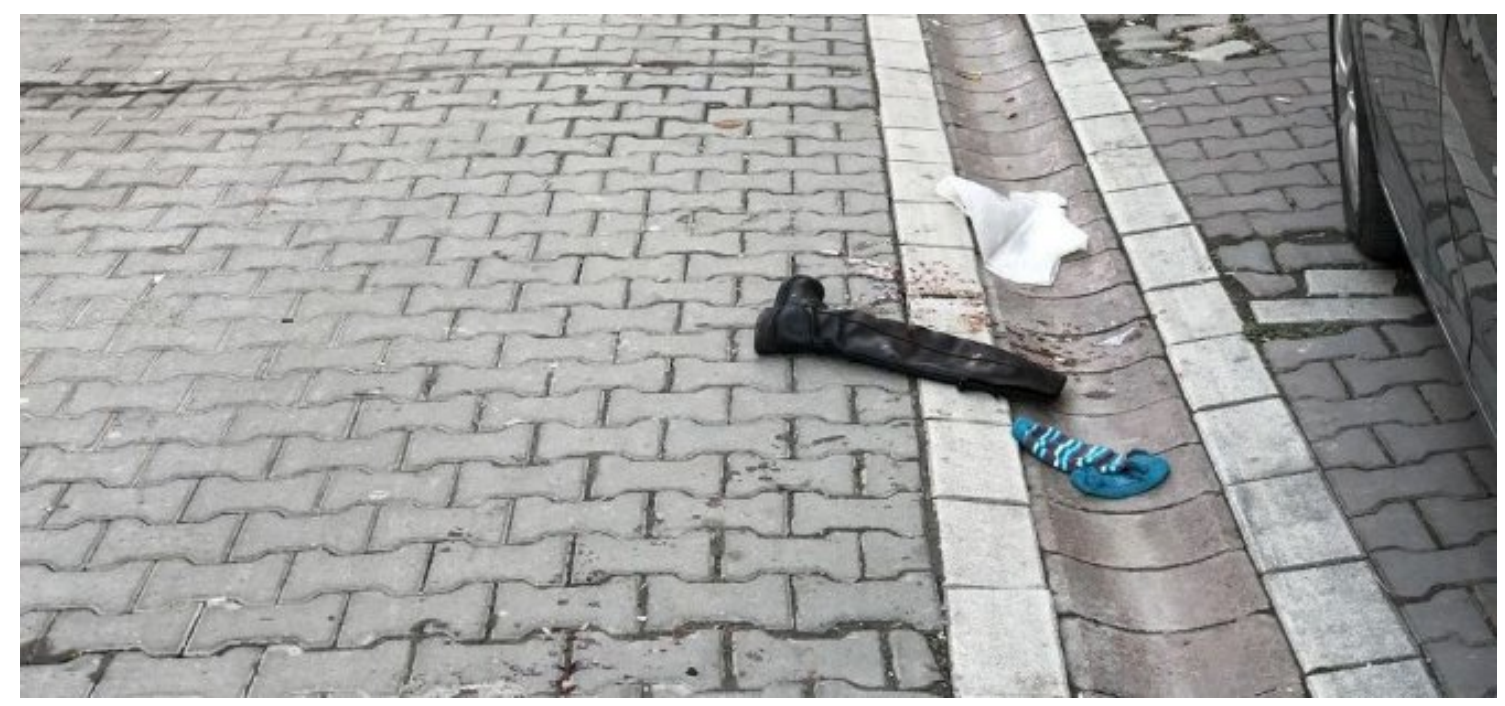

Fotoğraf 11. "Sevgilisini sokak ortasında vurdu, polise haber verip başında bekledi: 'Sonra kadın cinayetleri niye oluyor diyorsunuz'",

Kaynak: http://www.detaykibris.com/sevgilisini-sokak-ortasinda-vurdu-polise-haber-verip-basindabekledi-sonra-kadin-cin-208257h.htm Erişim Tarihi:18.02.2020

İHA'nın haberine göre, İstanbul Esenyurt'ta bir kişinin sevgilisini dövdükten sonra, polise haber verip beklediği, polis geldikten sonra olay yerinden kaçan şahsın kadını öldürmekle tehdit ettiği ve sonra "kadın cinayetleri niye oluyor diyorsunuz. Bir kere erkeğe sormuyorlar ki niye öldürdü bu adam" diye bağırdığı ifade ediliyor. Bu olay egemen dilin, sosyo kültürel bir yansıması, aksı olarak kendini göstermektedir. Kendini yaşattığ 1 bu şiddet karşısında kullandığı dille aklamaya çalışan şahsın yaptığ 1 ya da söylemleri aslında bu tarz olaylarda toplumda görülebilen söylemler olarak karşımıza çıkmaktadır. 
Arslan H., Topal A. \& Dönük G. D. (2020). Türkiye'de Geleneksel Medya ve Yeni Medyada Kadın Kimliği Üzerinden Üretilen Haberlere Eleştirel Bakış. Dördüncü Kuvvet. 3 (1). 21-38

Sosyal medya aslında sadece korkulması gereken bir mecra değildir. Doğru ve bilinçli kullanıldığında toplumda farklılıkları bütünleştiren, acılarda ortaklığı sağlayarak yaraları sarmaya yarayan, ortak ses olabilen, eğitici, öğretici bir mecradır da aynı zamanda. Bu nokta da aslında sosyal medya okuryazarlığı, medya okuryazarlığı karşımıza çıkmaktadır. Sadece kadın cinayetleri açısından değil erkeklere yönelik haberlerde de doğru kullanıldığında sosyal medyanın bütünleştirici etkisi görülebilmektedir. Ya da aynı ses, etkileme gücü kuvvetli bir mecra olarak yer alabilmektedir.

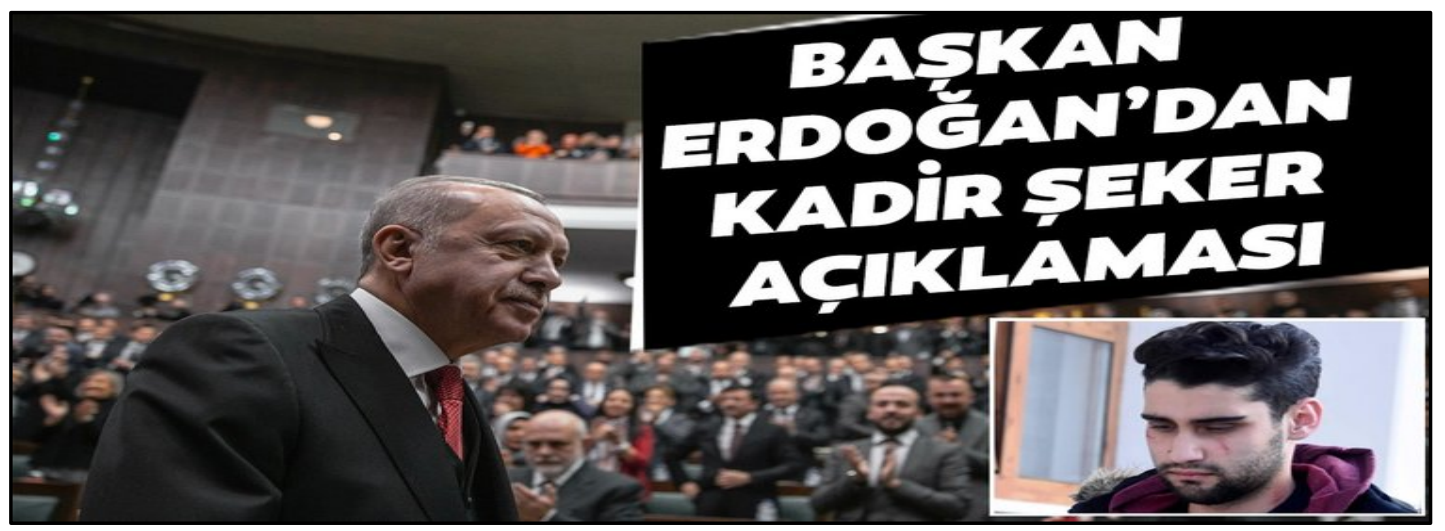

Fotoğraf 12 "Başkan Erdoğan'dan Kadir Şeker açıklaması! "Temenni ederiz ki adil bir karara varırlar..." Kaynak: https://www.sabah.com.tr/gundem/2020/02/12/son-dakika-baskan-erdogandan-kadir-sekeraciklamasi Erişim Tarihi:20.02.2020

Konya'da üniversite sınavına hazırlanan Kadir Şeker adlı bir gencin, şiddete maruz kaldığını gördüğü bir kadına yardım etmek isterken bir adamın ölümüne sebebiyet vermesi üzerine medyada çok sayıda haber yer almıştır. Kadir Şeker olayı sosyal medyada da, gündemde ağırlıklı olarak yer bulan bir konudur. Yaşanan bu olayda kadın kimliği üzerinden yürütülen haberlerde aktör kadın olmasına karşın bir erkeğin mağdur konumda olması sosyal medya üzerinden oldukça sık paylaşımla dile getirilmiş bir durum olarak karşımızda durmaktadır. Bu olayla ilgili olarak cumhurbaşkanı devreye girmiş, sosyal medyanın bu olayı işleme şekli ve sıklığı devletin en tepesini de harekete geçirmiş görünmektedir. Kadir Şeker'in, kaldığı yerde üniversite sınavına hazırlık için eğitim desteği gördüğü yönünde medyada çıkan haberler bulunmaktadır. Vicdanı ile hareket etmiş birinin yaşadıkları sosyal medyada çok ses bulmuş, bu olay karşısında toplum hemen hemen tek yürek olmuştur. Böylesi olaylar sosyal medyanın etkileme gücü, bireyler üzerindeki birleştirici etkisi üzerine ciddi kaynaklık edecek veriler sunmakta, önemli göstergeler olarak karşımızda durmaktadır. Sosyal medya hep kötü, olumsuz örnekleri içeren bir mecra değil, çözüm sunucu olarak da karşımıza çıkıyor. Burada eleştirel medya çerçevesinden baktığımızda bu olay tüm boyutları ile ele alındığında eleştirel medya okuryazarlığının eğitimsel bir çıktısı olarak olaylara tek bir pencereden bakmak yerine pek çok farklı açıdan bakmamız gerektiğini de öğretiyor.

İnternet gazeteciliğinde geleneksel medyaya göre en önemli farklılık, zaman, yer, içerik aktarımında herhangi bir sıkıntı yaşanmaması durumudur. Oldukça önemli bu fark yaşanan tüm olayları özellikle anlık iletiler vasitasıyla kullanıcılara ulaşan haberlerle, sosyal ağlar üzerinden bireyler seslerini daha rahat duyurabilmekte, olaylara karşı yapılan haberlere karşı geri bildirim daha kolay gerçekleşebilmektedir.

Çakır, internet gazeteciliğinin sağladığı imkânları şu şekilde sıralamıştır:

- Haberin oldukça hızlı bir şekilde okura aktarılarak devamlı güncellenebilmesi,

- Okurun habere dilediği an ulaşabilmesi, - ses ve görüntülü dosyaları kullanabilme,

- İstenilen haberlere kolayca ulaşılabildiği gibi, istenilen haberlerin de saklanabildiği,

- Okurla interaktif etkileşim ve okurun anlık geri bildirim imkânı,

- Haber içeriklerine rahatlıkla ulaşabilme,

- Farklı haberlere farklı kaynaklardan ulaşabilme, okurun haber oluşumuna anında verebildiği tepki ile etki etmesi (Çakır, 2007:140). 
Arslan H., Topal A. \& Dönük G. D. (2020). Türkiye'de Geleneksel Medya ve Yeni Medyada Kadın Kimliği Üzerinden Üretilen Haberlere Eleştirel Bakış. Dördüncü Kuvvet. 3 (1). 21-38

Sosyal medyanın uzmanlık gerektirmeyen kullanıcının rahatlıkla içeriğe katılım sağlaması, sosyal medya içeriklerinin üzerinde geleneksel medyaya göre düzeltme yapılmasını sağlamaktadır (Göker \& Keskin, 2015: 864).

İnsanların bu kadar özelinin yayılmasını gözlemek, gözetlemek, takip etmek, merak etmek duygularıyla ya da bir kişinin yaşadığı sıkıntılı durum karşısındaki hislerini umursamadan üzerine yorum yapabilmek yeni medyanın aslında kuralsızlıklarla örülü tarafının etik boyutu ile tam olarak yasal düzenlemelerle şekillenmesi gerekliliğini bir kere daha gözler önüne sermektedir. Haberler verilirken Tekeli'nin ifade ettiği gibi şiddet haberlerinde mağdurun ailesinin de göz önünde bulundurularak haber yapılması, mağdurun fotoğrafının mümkün olduğunca kullanılmaması ya da kullanılsa dahi buzlanarak verilmesi, habere ilişkin detayların aktarımında toplumu bilinçlendirecek ögelerin verilmesi, ölüm, kan, gibi toplum psikolojisini sarsacak ve umutsuzluk ya da kanıksama yaratacak unsurlar üzerinden verilmemesi gerekmektedir (Tekeli, 2016: 141).

Gökulu ve Hosta yaptıkları çalışmada kitle iletişim araçlarının toplumdaki şiddetin her ne kadar başlıca kaynağı olmasa da yaşananları meşrulaştıran, mağdurlar üzerinde ikinci bir mağduriyet oluşumuna neden olabildiklerini ifade etmişlerdir. Bu durumun sorumlu gazetecilik anlayışı çerçevesinden hareketle, kullanılan haber diline dikkat edilerek ve toplumdan her kesimin bu haberlere ulaşabileceği unutulmadan şiddeti onaylayan dilden kaçınarak haber yapılması gerekliliğine dikkat çekmişlerdir (Gökulu \& Hosta, 2013: 1847).

\section{Sonuç}

Cilt bakımı, sağlıklı yaşam, ev aletleri, beslenme, yemek, çocuk bakımı gibi başlıklar altında girilen içerikler çoğunlukla kadın kimliği üzerinden haberleştirilmekte, haber üretimleri kadınlar üzerinden gerçekleştirilmektedir. Erkek kimliği üzerinden haberler ise çoğunlukla siyaset, spor, ekonomi alanında haberler olarak sıklıkla karşımıza çıkmaktadır.

Kadın kimliği kullanılarak yapılan haberler başlıklar altında örneklerle verilecek olursa genel olarak bakıldığında yeni medya ve geleneksel medyada ortak kullanım kadının şiddete maruz kalmış hali fazla kullanılanlar arasında gözlemlenmektedir.

Geleneksel medyada yer alan haberlerde yer ve zaman sıkıntısı verilen haberlerin içeriklerini sinırlandırmaktadır. Ancak yine de detaylı haberler verilmektedir. Yeni medyanın olanakları ile bu sınır ve zaman kavramı daha üst boyuta taşınmış verilebilecek tüm ayrıntılar aktarılmaktadır. Olayı yaşayan, olayda mağdur olanların ve mağdur yakınlarının yaşadıkları, sonrasında yaşanacaklar düşünülmeden yapılan haberler, paylaşılan görseller aslında yeni travmaları, sosyal boyutta yaşanacak psikolojik sıkıntıları beraberinde getirebilecektir. Kadınların seslerini duyurmaları açısından belki de daha etkili bir mecra olan sosyal medya ya da yeni iletişim olanakları bu ölçüde beraberinde getirdiği gözetleme, mahremiyet, özel yaşam ihlallerini barındırmaktadır. Her şeyin rahatlıkla farklı anonim kimlikler altında paylaşılabildiği bu mecrada kadın kimliği üzerinden üretilen haberler, kadınların yerleşik rolleri üzerinden süregelmektedir. Ancak yine de geleneksel medyadan farklı olarak artık üretilen haberler mahremiyet kavramının sınırlarının yeni medya ile birlikte daha da zorlanmasıyla, içeriklerde daha çok detaya dayandırılması şeklinde karşımıza çıkmasıdır. Özellikle cinayet haberleri üzerinden yürütülen çalışma göstermiştir ki kadın kimliği üzerinden üretilen haberlerin içerikleri yeni medya olanakları çerçevesinde mahremiyet, özel hayatın gizliliği haklarına pek de dikkat edilmeden, habere konu kişiler ve yakınları etik kurallar çerçevesinde değerlendirilmeden sunulmaktadır. Hatta yeni medya olanakları içerisinde kadın kimliği üzerinden üretilen haberlerde cinsiyetçi söylem daha net gözlemlenmektedir. Kullanılan fotoğraf, görseller, videolar, kelimeler detaylandırılarak ve elinde akıllı telefon bulunan herkesin paylaşımları üzerinden üretilebilmektedir. $\mathrm{Bu}$ haberlerin etik kurallar çerçevesinde sınırlandırılıp değerlendirilmesi bu mecralarda oldukça zor görünmektedir. Ancak durum bir an önce yasal bir düzenleme ile en azından kurumsal yapılar için bir şekilde kontrol mekanizmasının işlerlik kazanması gerekliliğini göstermektedir. 
Arslan H., Topal A. \& Dönük G. D. (2020). Türkiye'de Geleneksel Medya ve Yeni Medyada Kadın Kimliği Üzerinden Üretilen Haberlere Eleştirel Bakış. Dördüncü Kuvvet. 3 (1). 21-38

Haberlerin hipermetinsellik özelliği de geleneksel medya ile yeni medya arasındaki önemli farklardandır. Bir internet gazetesinde okumaya ya da incelemeye başladığınız haberi, hipermetinsellik özelliği sayesinde haber içi linkler aracılığıyla farklı gazete ve internet sayfalarına erişerek, başladığınız noktadan çok farklı bir noktada tamamlayabilirsiniz. Artık geleneksel medyada da ya da geleneksel gazetecilik içerisinde de sosyal medyada yer almayan kuruluş yok gibidir. Yani bir anlamda sosyal medyada yani sanal ortamda var olmak günümüzde zorunluluk gibi olmuştur. Kitlelere sunulanlar yeni medya olanakları sayesinde dünyanın öteki ucuyla bağlantı sağlanabilmektedir.

Geleneksel ve yeni medya da yer alan kadın kimliği üzerinden üretilen haberler çalışma kapsamında ele alınan haberler açısından değerlendirildiğinde; haberlerde kullanılan dil, kelimeler genel olarak aynı tarzda olmakla birlikte haberin arka planına yeni medyanın hipermetinsellik ve multimedya özellikleri ile daha ince ayrıntılara hızlı erişim sağlandığı gözlenmektedir. Bu bağlamda kadınlar sosyal medya aracılığıla her ne kadar seslerini daha rahat duyurup organize olabilseler de genel olarak yapılan haber içeriklerine etik kurallar bağlamında pek de dikkat edildiği söylenememektedir.

Şiddet her haliyle medyada yer bulmaktadır. İnternet üzerinden sosyal medyada, geleneksel medyada her biçimi ile sıklıkla haberlere konu edilmektedir. Sadece kadına yönelik olarak gerçekleşen şiddet değil ancak şiddetin her biçimi habere konu olacak unsur olarak yeni medya ve geleneksel medyada yer bulmaktadır. Ancak özellikle üzerinde dikkat edilmesi gereken sosyal medyanın etik ihlallerin sıklıkla gerçekleşebildiği bir mecra olması bağlamında tüketici konumdaki bireylerin haber üretiminde aldıkları yerdir. Yapılan paylaşımlar kurumsal bazda değerlendirildiğinde etik ihlaller noktasında daha kolay önlem alınabilecekken bireysel bazda paylaşılan içeriklerin denetiminin zorluğu bu mecraların tehlikeli olabilecek boyutlarını gözler önüne sermektedir.

Bunun yanında yeni medya ya da sosyal medya sadece tehlikeli olabilecek paylaşımların yapıldığ olumsuz içeriklerle dolu bir mecra olarak tek başına bu açıdan değerlendirilmemelidir. Sosyal medyanın bütünleştirici, sosyalleşmeye, anlık paylaşıma, yardımlaşmaya, toplumsal bütünleşmeye olanak tanıdığı, olumlu unsurları olan tarafları da unutulmamalıdır. Sürekli gelişen ve değişen teknolojiye ayak uydurmak, gelişmelerden haberdar olmak, yeni iletişim teknolojilerinin hayatımıza sağladığ 1 kolaylıklar unutulmamalıdır. Ayrıca son dönem doğan z kuşağı bireyler yeni iletişim teknolojileri ile bütünleşmiş durumdadırlar. Hayatlarından bir parça olmuş akıllı telefonlar, teknolojik aletler neredeyse vücutlarının birer parçası haline gelmiş bu bireylere yönelik olarak temelden başlayarak verilecek medya okuryazarlığı ve sosyal medya okuryazarlığı eğitimi etik konuda daha duyarlı bireyler yetişmesine, bu mecraların daha doğru kullanımına olanak tanıyacak çok önemli noktalardır. Toplumun haber ve bilgi alma hakk1, toplum menfaatleri, toplumun genel yarar ve bütünlüğü düşünülerek medya çalışanlarınca, etik kurallar çerçevesinde değerlendirilerek verilmelidir. Medya çalışanları dışındaki bireylerin de özellikle şiddet içerikli haber ve bilgi paylaşımında toplum menfaatlerini düşünmeleri, mağdur ve mağdur yakınları çerçevesinde empati kurarak haber vermeleri gerekmektedir.

Haber etiği açısından toplumsal bilinç oluşturabilmek adına kamuya yönelik açıklayıcı yayınlar ve bilinçlendirici paylaşımlar sosyal medya, geleneksel medya üzerinden sonraki dönemler için önlem noktasında birer adım olarak yer alabilecektir.

\section{Kaynakça}

Çakır, H. (2007). Geleneksel Gazetecilik Karşısında İnternet Gazeteciliği. Sosyal Bilimler Enstitüsü Dergisi, 123-149.

Çambay, S. O. (2015). Bir Toplumsallaşma Aracı Olarak Yeni Medya: Kuramsal Bir Değerlendirme. Karabük Üniversitesi Sosyal Bilimler Enstitüsü Dergisi, 237-247.

Öztürk, Ş. (2015). Sosyal Medyada Etik Sorunlar. Selçuk Üniversitesi Illetişim Fakültesi Akademik Dergisi, 287-311.

Aktaş, C. (2007). Yeni Medyanın Geleneksel Medya İle Karşılaştırılması. G. Erol içinde, Medya Üzerine Çalışmalar. İstanbul: Bera Yayınları. 
Arslan H., Topal A. \& Dönük G. D. (2020). Türkiye'de Geleneksel Medya ve Yeni Medyada Kadın Kimliği Üzerinden Üretilen Haberlere Eleştirel Bakış. Dördüncü Kuvvet. 3 (1). 21-38

Aktaş, C. (2007). Yeni Medyanın Geleneksel Medya ile Karşılaştırılması. G. Erol içinde, Medya Üzerine Çalışmalar. İstanbul: Beta Yayınevi, 112-121.

Altunay, A. (2012). Geleneksel Medyadan Yeni Medyaya: Görüntü Yüzeyi. Selçuk Üniversitesi Sosyal Bilimler Enstitüsü Dergisi, 33-44.

Aydeniz, H. (2012). Medyayı Tanımak. İstanbul: Aile ve Sosyal Politikalar Bakanlığı.

Aydoğan, F., \& Kırık, A. M. (2012). Alternatif Medya Olarak Yeni Medy. Akdeniz İletişim Dergisi, 5869.

Binark, M. (2007). Yeni Medya çalışmalarında Yeni Sorunlar. M. Binark içinde, Yeni Medya Çalışmaları. Ankara: Dipnot Yayınları, 21-44.

Binark, M., \& Bayraktutan, G. (2013). Ayın Karanlık Yüzü Yeni Medya Ve Etik. İstanbul: Kalkedon Yayınlar1.

Dilmen, N. E. (2007). Yeni medya kavramı çerçevesinde internet günlükleri-bloglar ve gazeteciliğe yansımaları. Marmara Illetişim Dergisi, 113-122.

Dilmen, N. E., \& Öğüt, S. (2006). "Yeni İletişim Ortamları ve Etkileşime”e İletişimsel Bilişim

Yaklaşımı. Yeni İletişim Ortamları ve Etkileşim Uluslararası Konferansı. İstanbul: Marmara

Üniversitesi, 17-23.

Göker, G., \& Keskin, S. (2015). Sosyal Medya Türevi Olarak Sosyal İçerik Platformları: Betimsel Bir İnceleme. Uluslararası Sosyal Araştırmalar Dergisi, 861-874.

Gökulu, G., \& Hosta, N. ( 2013). Basında Kadına Yönelik Şiddet Haberlerinin Analizi:Hürriyet, Sabah ve Posta Gazeteleri Örneği (2005-2008). International Journal of Social Science, 1829-1850.

Geçer, E. (2016). Eski Adet, Yeni Medya: Kadınlar, Haklar ve İnsanlar. A. Z. Özgür, \& A. İşman içinde, Illetişim Çalışmaları. Sakarya: Sakarya Üniversitesi, 387-400.

Genel, M. G. (2016). Sosyal Medyada "Kimlik Bunalımı". M. G. Genel içinde, Yeni Medya

Araştırmalart-2. Bursa: Ekin Yayınevi, 1-23.

İrvan, S. (2003). Medya Ve Etik . S. Alankuş içinde, Medya Etik Ve Haber. İstanbul: IPS İletişim Vakfı Yayınlar1, 51-83.

Kılınç, B., \& Kılınç, E. P. (2014). Yeni Medya Ortamında Çocuk Birey:Yeni İletişim Teknolojileri ve Medya Pedagojisinin Önemi. Akdeniz İletişim Dergisi, 9-23.

Kuyucu, M. (2016). Geleneksel Gazetecilikte Sosyal Medya Uygulamaları:Gazetelerin Twitter Hesaplarında Paylaştığı Haberlerin Etkileşimleri Üzerine Bir Araştırma. A. Z. Özgür, \& A. İşman içinde, İletişim Çalı̧̧maları. Sakarya: Sakarya Üniversitesi, 418-452.

Sözeri, C. (2012). Sosyal Medya Gücüyle Geleneksel Medyayı Değiştirmek Mümkün Mü? T. Kara, \& E. Özgen içinde, Sosyal Medya. İstanbul: Beta Yayıncılık, 269-284.

Söğ̈̈t, F. (2019). Yeni Medya ve Temsil: İnternet Gazeteciliğinde Toplumsal Cinsiyet Kimliklerinin Sunumu. Akdeniz Illetişim Dergisi, 212-231.

Tekeli, E. S. (2016). Kadın cinayetlerinin haberleştirilmesi bağlamında medya etiğini yeniden tartışmak: Habertürk gazetesi örneği. Abant Kültürel Araşttrmalar Dergisi, 129-142.

Uğurlu, Ö. (2015). Kadının Benlik Sunumunun Güncel Bir Aracı Olarak Sosyal Ağla rBir Tasarım Unsuru: 'Kusursuzlaştırma'. Uşak Üniversitesi Sosyal Bilimler Dergisi, 231-248.

Vardal, Z. B. (2015). Yeni Medya ve Etik. International Multilingual Academic Journal, 95-103.

Vural, Z. B., \& Bat, M. (2010). Yeni Bir İletişim Ortamı Olarak SosyalL Medya: Ege Üniversitesi İletişim Fakültesine Yönelik Bir Araştırma. Journal of Yaşar University, 3348-3382.

Yanık, A. (2016). Yeni Medya Nedir Ne değildir? Uluslararası Sosyal Araştırmalar Dergisi, 898-910. Yurdigül, Y., \& İspir, N. (2015). Yeni Medyada Haber. M. G. Genel içinde, Yeni Medya Araştırmalart1. Bursa: Ekin Yayınevi, 43-62. 